\title{
News Media Criminology
}

\section{Chris Greer, City University London}

Greer, C. (2010) 'News Media Criminology', in McLaughlin, E. and Newburn, T. (eds) The Sage Handbook of Criminological Theory, London: Sage.

\section{Introduction}

The news media are a defining feature of the crime and justice landscape. Especially today in a globalised context of hyper-mediatisation and high crime consciousness, news media representations are key indicators of the nature and extent of crime, the appropriateness and efficacy of criminal justice, and the wider state of the nation. Yet serious attention to news media within criminology has historically been patchy and recently appears alarmingly to have dropped off the radar. This chapter discusses the major theoretical issues and debates that have shaped what might loosely be termed news media criminology in Britain. It identifies key interventions, situating them both theoretically and chronologically in order to document the development of the field. What becomes apparent is just how few of the definitive interventions have come from within criminology. From its origins in the 1960s, the field of news media criminology was characterised by prolific and engaged research and a voracious interdisciplinarity that cut across the emerging areas of critical criminology, sociology of mass communications, media studies and cultural studies. Today, only research on content abounds and, as criminology has made the transition from field to discipline, that original enthusiasm for interdisciplinarity has been replaced with disciplinisation and selfreferentialism.

For the purposes of discussion, the theoretical history is divided into two broad categories corresponding with two broad time periods: Marxist and Post-Marxist. The period of Marxist interventions - roughly from the 1960s to the 1980s - was characterised by theoretical homogeneity. There were debates and conflicts within Marxism, and a wider context of theoretical pluralism within criminology. But the overriding concern shared across studies on news media, crime and justice was the reproduction of 'dominant ideology' and, though it was not always articulated in these terms, the legitimation of the 'Authoritarian State'. The question was not whether Marxism, but which Marxism. The PostMarxist period, in contrast, has been characterised by theoretical heterogeneity and fragmentation. There were direct challenges to Marxist readings from within, and the expansion of traditional class-based notions of 'dominant ideology' to embrace gender and ethnicity. But this period has also seen the emergence of new frameworks for understanding crime news that seek to move beyond the reproduction of 'dominant ideology' as the paradigmatic concern.

The first part of this chapter focuses on the Marxist and Post-Marxist theoretical perspectives that have shaped the field of news media criminology in Britain, bearing in mind that the most influential studies have not all been British. The second part explores 
some of the key theoretical concepts that have remained central to research on news media, crime and justice - newsworthiness, fear of crime and moral panic. The final part discusses current dilemmas in theory and research and suggests that new intellectual resources are needed to engage with the rapid, intersecting transformations in the crime, justice and media environments. In closing, I point to some areas that might benefit from further theoretical and empirical attention.

\section{Theoretical Perspectives}

Two theoretical paradigms shaped news media research in the $20^{\text {th }}$ Century - the liberal pluralist paradigm and the control paradigm. Liberal pluralist approaches are underpinned by the ideals of classical liberal theory, and emphasize the principles of freedom, choice and democracy. From this perspective, news selection and production is shaped by public interests and consumer demand, the sovereignty of professional journalistic values, equal competition for media access by a diversity of news sources, and the collective values of a society built around more or less organic consensus. The role of the news media is to accurately inform audiences, protect democracy and serve the interests of the social majority. In contrast, control approaches are influenced by Marxist and critical theory, and stress the unequal distribution of economic and cultural power throughout society. Here, news selection and production is shaped by elite interests and the demands of capitalist enterprise, implicit and explicit constraints on media workers' professional autonomy, the dominance of a narrow range of powerful sources, and the normalisation of ruling class values throughout a society built around a manufactured consensus. From this perspective, the role of news media is to reproduce dominant ideology, legitimate the capitalist system, and thus serve the interests of the ruling elite. The liberal pluralist paradigm tends to be popular among media practitioners and those who command cultural, economic and political power. The control paradigm has been far more influential within the academy, and has predominated in research on news media, crime and justice.

\section{Marxist Interventions}

Three institutional Centres drove the development of British news media research in the sixties and seventies: the Birmingham Centre for Contemporary Cultural Studies (CCCS) at Birmingham University, the Centre for Mass Communication Research (CMCR) at Leicester University and the Glasgow University Media Group (GUMG). None of these Centres were primarily criminological, yet their influence on theorising news media, crime and justice has been profound. The Centres were united in their rejection of the largely American tradition of liberal pluralism. Each advocated the multidisciplinary study of the communication process as a whole. And each sought to investigate media influence at the level of everyday social action rather than individual psychology. Ultimately, they were all concerned to understand the role of news media in the reproduction of 'dominant ideology'. Alongside 
their commonalities, however, there were important differences. Not least of these were the Centres' different foundational disciplines and, relatedly, their contrasting readings and applications of Marxism and critical theory. The CCCS synthesised cultural studies and structural Marxism. The GUMG established a critical media studies that retained the actionorientation of an instrumental Marxism. And the CMCR used the sociology of mass communications to develop a critical political economy. It is useful to briefly summarise some of the key differences between these readings of Marx, before considering how they shaped the work that each centre produced.

\section{Situating Marx}

Instrumental Marxists are concerned with how economic, political and cultural elites use their power in a market society to ensure that information flows and exchanges reinforce their own minority capitalist interests. This action-oriented reading of Marx requires on some level the acceptance of a unified elite with shared intent that is sufficiently coherent to manage the media in a uniform fashion. The media in this model are seen to work more or less directly in the service of the ruling class, and media content is shaped internally through newsroom hierarchies and journalistic self-censorship, and externally through direct pressures from, for example, advertising agencies, big business and government.

Structural Marxism detaches the workings of key structures and institutions - the state, the economy, the law, the education system, the media - from the conscious agency of the individuals within them. State institutions are seen to operate with relative autonomy, but nonetheless function together as part of a system that is structurallyoriented to maintaining the dominance of the capitalist order. Structural Marxist media analysts are interested in how systems and processes of signification and representation collectively reproduce dominant ideology at the levels of popular discourse, understanding and everyday rituals, thus ensuring its normalisation and acceptance throughout society. Both instrumental and structural Marxists adhere to the base-superstructure metaphor and tend to remain faithful, in the final instance, to the notion of economic determination. But whereas an instrumental Marxist position sees power acting in a conscious, top-down manner, relatively unchallenged, structural Marxists highlight the contested nature of ideology and the requirement for dominant interests to be constantly re-negotiated and legitimated through state apparatuses and practices. News production here is structurallyoriented, rather than individually directed, to reinforce the dominant ideology.

Finally, political economy theorists reject the action-oriented, interventionist approach adopted by instrumental Marxists, but are also critical of what is seen as structural Marxism's over-reliance on ideological factors. Political economists focus their analyses on the relations between the economic processes and structures of media production and the ideological content of media. Unlike structural Marxists, who view ideology as relatively autonomous and more than simply a reflection of the economic base, political economists see ideology, along with other cultural processes, as of secondary importance to and determined by the economic requirements of capitalist accumulation. And whereas 
structural Marxists see ideology as a site of ongoing struggle, political economists tend to view ideology as the means through which struggle is obliterated (Curran et al, 1982). It is those who command the greatest resources who ultimately achieve greatest success in putting their point of view across in news media coverage. Resource-starved organisations find themselves marginalised, and frequently excluded from the communications process altogether.

\section{Institutional Readings}

The central research interest of the CCCS was the relationship between popular culture and ideology and, in particular, the issue of meaning: how it is produced, ordered, negotiated how it shapes and situates everyday existence at the level of cultural and social practices. Hall (1973) rejected the long-standing notion that meaning is an essential or fixed quality of media texts, insisting instead that they are 'polysemic' and can be read in multiple ways. How texts are 'encoded' by producers has no necessary connection with how they may subsequently be 'decoded' by consumers. Meaning was thus conceptualised as fluid, dynamic and subject to the influence of wider contextual factors like gender, race and class. Yet it can nonetheless be structured and ordered in particular ways through ideology. Thus a key concern was to understand how dominant ideology was reflected and reinforced in the mass media, and how it may variously be appropriated, resisted or subverted by everyday consumers. The CCCS's particular form of Marxism derived from a synthesis of Althusser's structuralism, Gramsci's writings on hegemony, and Barthes' semiotic work on texts. The resulting theoretical framework retained the core concerns of a structuralist approach, but sought to overcome what were seen as the restrictions of economic determination. Rather than being determined in any straightforward sense by the economic base-superstructure model, ideology was viewed as being implicitly embedded in all cultural structures and practices, including media production. This structural-culturalist approach to understanding news media and ideology was most influentially applied in Hall et al's (1978) Policing the Crisis.

Hall et al (1978) explore the creation of a moral panic around 'mugging' during a period of economic recession, high unemployment and social unrest they identify with a 'crisis in hegemony'. Sensational media coverage of this 'new' crime wave simultaneously tapped into existing fears around law and order, race and social decline, and provided a folk devil - the young black street criminal - against whom all 'respectable' people could unite. The moral panic, and the wider sense of crisis it simultaneously invoked and represented, generated the right conditions for the state to reassert and relegitimate itself - policing the crisis, crucially with the consent of the people, by cracking down on the problem of crime. As Jefferson recalls (2008: 114), the authors were interested in understanding how the relatively autonomous institutions of the state - the police, the judiciary and the media (Althusser's (1971) ideological state apparatus) - contributed to the panic independently, whilst simultaneously functioning collectively to reproduce the ideas of the ruling class: the dominant ideology. They suggested that dominant ideology is continually reproduced in the 
media because news production is structurally oriented, in the name of journalistic 'objectivity' and 'impartiality', to appeal first to those accredited experts who represent and command institutional power. This places powerful groups in the position to establish 'an initial definition or primary interpretation of the topic in question' (Hall et al, 1978: 58). Once the primary definition has been established it is extremely difficult to override, and future debate is contained within a forum of 'controlled discourse', governed by the primary definers:

The media, then, do not simply 'create' the news; nor do they simply transmit the ideology of the 'ruling class' in a conspiratorial fashion. Indeed, we have suggested that, in a critical sense, the media are frequently not the 'primary definers' of news events at all; but their structured relationship to power has the effect of making them play a crucial but secondary role in reproducing the definitions of those who have privileged access, as of right, to the media as 'accredited sources'. From this point of view, in the moment of news production, the media stand in a position of structured subordination to the primary definers (Hall et al, 1978: 59).

In this reading, powerful institutional sources are the primary definers, while the media are reduced to playing a secondary role. Journalists are largely stripped of agency and influence. Their autonomy is removed.

Like the CCCS, the GUMG were motivated to explore 'the vexed questions of cultural power and the consensual legitimation of beliefs' (1976: 14 ) and both Centres were united in their rejection of economic determinism. While the 'simple 'base/superstructure' view of broadcasting might account for a small proportion of output', they argued, 'it can in no way explain and analyse the inherent contradictions and varieties of permitted views and the surface openness that exists across the range of broadcasting output' (GUMG, 1980: 412). The GUMG's first major research project, Bad News (1976), combined quantitative and qualitative content analysis, supplemented with interviews and participant observation, to analyse television news coverage of industrial disputes (see also Eldridge, 2006). They found a clear absence of alternative views or comment to challenge the dominant ideological position, and explained what they call news 'bias' as follows (GUMG, 1976: 267-268):

Our analysis goes beyond saying merely that the television news 'favour' certain individuals and institutions by giving them more time and status. Such criticisms are crude. The nature of our analysis is deeper than this: in the end it relates to the picture of society in general and industrial society in particular, that television news constructs. This at its most damaging... includes the laying of blame for society's industrial and economic problems at the door of the workforce. This is done in the face of contradictory evidence which, when it appears, is either ignored, smothered, or at worst, is treated as if it supports the inferential frameworks utilized by the producers of news. 
From this perspective media personnel are empowered with an agency and intentionality they are denied in the work of the CCCS. The GUMG's follow-up study More Bad News (1980: 400) confirmed this view, finding that journalists 'actively embrace' the dominant ideological viewpoint 'in a way that would be hard to justify as impartial'. Their activities include 'not only the agenda-setting functions we have described, but also a systematic partiality in the reporting and interpretive use of government statistics' (1980: 401). Here, journalists are not secondary players, 'structurally subordinated' in a communication process shaped by the cultural and economic power of state institutions. They are primary definers, and news is conceptualised as 'the manifestation of the collective cultural codes of those employed to do this selective and judgemental work for society' (1976: 14). Hall (1978) interpreted this action-oriented reading as a weakness, an instrumentalism betraying a 'simplistic notion of television 'bias'... as though simply directed by the 'ruling class". Conversely, the GUMG saw in the CCCS a structural determinism that blinded them to, or, still worse, rendered insignificant the agency of news personnel and the crucial intervening role of senior media managers on the basis of fractional class interests.

The Centres also differed in their approach to empirical research. Whereas the CCCS drew from Louis Althusser, a structural Marxist who retained a deep scepticism toward empirical analysis, the GUMG identified more readily with Ralph Miliband, an instrumental Marxist who vociferously defended it. For Althusser, power operates in a non-linear fashion and derives from a set of 'hidden relations' that defy direct empirical investigation. However, underpinning structures of power, ideology and meaning can be revealed through theoretical analysis. From this perspective, research should be theory-led. More mundanely, the CCCS was poorly funded and staffed largely by humanities graduates with limited formal training in conducting empirical research. For financial and intellectual reasons, then, their primary research site was the text, not the street. Of course, much empirical work was carried out at the CCCS, including classic ethnographies (Willis, 1977; Hebdidge, 1979) and the groundbreaking audience research by Morley and Brunsdon (Morley, 1980; Brunsdon and Morley, 1978). But throughout the 1970s it was inconsistent and sometimes marginalised in studies that prioritised theoretical sophistication. In Resistance Through Rituals (1976), for example, 'literary ethnography' takes the place of direct empirical observation (Blackman, 1998). And despite its detailed, if unsystematic, newspaper content analysis, the key focus of Policing the Crisis, as Bennett notes (1982: 302), is less on the relationship between ideology and 'reality', and more on the relationship between ideologies. In contrast, the GUMG developed what they describe as a 'positivist critique, though not in any arcane sense of limiting itself to checking and producing the facts'. The aim in Bad News (1976) was to analyse how 'viewers were given a misleading portrayal of industrial disputes in the UK when measured against the independent reality of events' (1980, xiii). For this group of just-as-poorly-funded but empirically trained sociologists, developing theory should not come at the expense of empirically testing it. This, for the GUMG, was a fundamental problem within the CCCS and cultural studies more generally. 
Privileging the symbolic over the material simultaneously privileges the abstract-theoretical over the substantive-empirical. Theory is enough: no further evidence is required (Philo, 1999 ; Philo and Miller, 2001).

The political economy approach of the Leicester CMCR was grounded in the sociology of mass communications, and empirically-oriented. The aim was to explore the relations between the economic structure and organization of the cultural industries, their ideological content, and wider social, cultural and political life. With respect to media production, the CMCR sought to understand the role of mass communications in the maintenance and legitimation of structural inequalities in a class society. Whilst the CCCS and the GUMG were united in their rejection of economic determination, the CMCR placed economic forces at the heart of the media production process. For Murdock and Golding (1977:37) these forces:

...work consistently to exclude those voices lacking economic power or resources... the underlying logic of cost operates systematically, consolidating the position of groups already established in the main mass-media markets and excluding those groups who lack the capital base required for successful entry. Thus the voices which survive will largely belong to those least likely to criticize the prevailing distribution of wealth and power. Conversely, those most likely to challenge these arrangements are unable to publicize their dissent or opposition because they cannot command resources needed for effective communication to a broad audience.

Members clearly acknowledged the relevance of other factors in the news production process, including the 'controls and constraints imposed by the state and the political sphere' and 'the inertia exerted by dominant cultural codes and traditions' (Golding and Murdock, 1979: 198). They also accepted the "relative autonomy' of production personnel and the 'pertinent effects of professional ideologies and practices' (ibid.). But these factors were of secondary importance to the material and determining impact of economic forces. The Leicester CMCR's political economy approach thus represented a return to the basesuperstructure metaphor. The role of media is that of "legitimation through the production of false consciousness, in the interests of a class which owns and controls the media' (Bennett, 1982: 26). This macro-sociological account of control through concentration of ownership, monopolisation and diversification lay beyond the reach of a micro-oriented culturalist framework. As Golding and Murdock (2000: 72) put it, 'Cultural studies offers an analysis of the ways the cultural industries work that has little or nothing to say about how they actually operate as industries, and how their economic organisation impinges on the production and circulation of meaning. Nor does it examine the ways in which people's consumption choices are structured by their position in the wider economic formation. Exploring these dynamics is the primary task for a critical political economy of communications'. 
In one of the CMCR's first major texts, Halloran, Elliott and Murdock (1970) analysed press and television reporting of the 1968 Vietnam demonstrations in London's Grosvenor Square. Building on the work of Lang and Lang (1955) and Boorstin (1963), they developed the notion of 'inferential structures' - frameworks which guide journalists' construction of 'events as news' on the basis of values and definitions already legitimated in the public mind; that is, on the basis of the prevailing consensus:

The media can create 'news' which is based not on the event itself but on those aspects of it to which they have assigned a particular prominence, i.e. the 'event as news'... in other words, the event achieves reality by being reported, while in addition consequences may flow from the report which actually shape the original reality in accordance with the meaning given to it by the 'news' (Halloran et al, 1970: 90).

By combining this framework with an analysis of 'news values' adapted from the work of Norwegian media researchers Galtung and Ruge (1965), Halloran et al (1970: 315, emphasis in original) illustrate the media's role in 'defining the situation and in cultivating the assumption that this is the way it is'. They illustrate how the demonstrations were defined early on as likely to involve violence between the forces of law and order (the police) and the forces of anarchy (the demonstrators). Though the protests turned out to be largely peaceful, the event was still reported in line with the dominant inferential structure - the 'framework of violence' - and thus it was the issue of violence, minimal though it was, that provided 'the news'. The influence of the CMCR's work on 'inferential structures' is evident in Hall's et al's (1978: 59) model of 'primary definition', and in the GUMG's analyses of television news 'bias' (GUMG, 1976, 1980). It also featured across a number of classic crime news analyses that emerged from the interdisciplinary environment of the time, most vividly encapsulated within the National Deviancy Conference.

\section{The National Deviancy Conference and the Violent Society}

As the Leicester and Birmingham Centres were developing their particular institutional research approaches in the late 1960s (the GUMG would not be established until 1974), a critical criminology was finding form in the National Deviancy Conference (NDC). The NDC was not contained within any one institution. Nevertheless, it constituted the institutionalisation of critical criminological theory and research. What is so striking about this period is that news media research commanded a significant presence within critical criminology; a presence that, for reasons outlined later in this chapter, is missing today. Though not a direct product of the NDC meetings, The Manufacture of News: Deviance, Social Problems and the Mass Media (1973) combined contributions by core NDC members with a series of previously published and original pieces by leading media researchers across a range of fields. Motivated by the belief that much mainstream media research was 'on the wrong lines', and deliberately stepping away from American mainstream concerns regarding the direct effects of media exposure, Cohen and Young (1973: 10) wanted to explore 'the 
conceptions of deviance and social problems revealed in the mass media and the implicit view of society behind such conceptions'. Hall and Murdock both provided chapters - Hall on the ideological role of news photographs, and the representation of violence (Hall, 1971, 1973), and Murdock (1973) on the reporting of political deviance. Other chapters analysed news values, representations of sexuality and race, and moral panics. The contributions encapsulated the Marxism and shared politics that defined news media criminology at that time, presenting work by the CCCS and CMCR side-by-side, and offered an clear, if critical, endorsement of control readings of news production.

The Marxist reading of news media, crime and justice was further reinforced by Chibnall (1977). Combining content analysis with interviews and observations, and drawing heavily from the work of the CCCS and the CMRC, Chibnall (1975: 115-116) established that law-and-order-news 'neutralizes deviant world views by either denying their status as beliefs which should be taken seriously by sensible people, or condemning them as manifestations of wickedness or corruption'. This elite-orientation is not, however, a 'product of editorial conspiracy, but a reflection of the social organization of reporting, and the professional imperatives and commercial interests which underlie it' (ibid.). The explanatory framework leans toward a structural rather than action-oriented understanding of news production. Regarding journalist-source power relations, Chibnall finds that 'the journalist is always in an inferior negotiating position - the journalist who cannot get information is out of a job, whereas the policeman who retains it is not' (Chibnall, 1977: 155). This notion of 'structured subordination' was simultaneously being developed in the CCCS mugging research and would find full articulation as the theory of 'primary definition' in Policing the Crisis (1978). Though the two studies emerged 'quite autonomously' (Chibnall, 1977: 76), they overlap significantly in their theoretical approach and substantive interest in how the press communicated public anxieties at a time of rapid social change and mobilised the blanket conceptualisations 'Violent Society' and 'Law and Order crisis' to capture the public imagination. The differences lie in their methodologies and overall aims. Chibnall (1977) used content analysis, interviews and observation to deconstruct crime news and identify its component parts, locating crime reporting within the wider context of press ideology and political economy. Hall et al (1978) employed content analysis to investigate the creation of a moral panic around mugging as part of wider efforts to legitimate the shift toward an authoritarian state at a time of hegemonic crisis. Chibnall looks at the everyday, while Hall et al focus on the exceptional; Chibnall theorises the ideological role of the news media, while Hall et al explore the news media to formulate a theory of the Authoritarian state.

\section{From Authoritarian State to National Security State}

In a study that postdates the British Marxist work by a decade, and remains influential in British news media criminology and critical criminology today, Herman and Chomsky (1988: 298) developed their 'propaganda model', in which 'the raw material of news' passes through five filters, 'leaving only the cleansed residue fit to print'. The five filters are media 
ownership and profit orientation, the influence of advertising, the role of experts, 'flak' as a means of disciplining the media, and anti-communism as the 'national religion'. Through meticulous empirical research on the reporting of 'terrorism' and close consideration of the media's alleged collusion in the 'criminalisation' of non-friendly regimes, Herman and Chomsky demonstrate how economic, political, military and cultural elites effectively conspire to control the content and flow of media information. As in much British Marxist research, journalists are seen to have little influence or autonomy in the news production process. Power lies with the state and large corporations. Whilst journalists may feel they are acting objectively and writing in accordance with prevailing and accepted journalistic news values, in practice they are subordinated to reproduce the interests of an active ruling elite. Thus, Herman and Chomsky cast the news media as a key functionary of the 'National Security State', operating to 'manufacture consent' around elite ideas in the name of the 'national interest' and, in so doing, engendering acceptance of a social order that reflects the interests of a powerful few, rather than the wider majority.

\section{The Decline of Marxism and the Fracturing of Critical Criminology}

Though different researchers got there by different theoretical and methodological means, and presented different levels of evidence to substantiate their respective claims, Marxist interventions shared an overriding concern with the power of ruling class interests to marginalize dissenting discourses and opinion and maintain the socio-cultural and economic status quo. By the late 1970s Marxism was losing influence within the social sciences, and the critical criminology that found collective expression in the NDC was fragmenting. When Manufacturing Consent (1988) was published in the US, itself running against the grain of more nuanced studies of news production, the Marxist turn in British social sciences had passed. With it, criminological interest in news media markedly declined. Critical Criminology split into four distinct domains - Critical Criminology, Left Realist Criminology, Governmental Criminology, and Critical Legal Studies (see McLaughlin, Chapter x, this collection).

For Critical Criminology the media's role in constructing the Authoritarian State and the Violent Society had been demonstrated: the media work had been done. For Left Realist Criminology, media research had been colonised by Critical Criminologists - an issue of moral panics, deviancy amplification and ideological mystification. Furthermore, in the victimisation survey Left Realists found a means to get behind media representations and ideological mystifications and to access the empirical reality of the crime problem: a problem, they insisted, was palpably not a media construction. For Governmental Criminology, Foucault provided news ways of exploring relations of power and knowledge at the level of micro-institutional discourses. Media discourses were of little interest in this context. And Critical Legal Studies focused on the operation of law, again with little space for media research. Within each of these new manifestations of critical criminology, news media work was no longer a priority. Within orthodox criminology the news media were then, as they are today, a curiosity to be engaged with between research projects and, even 
then, to be explored largely though positivistic, quantitative content analysis. Thus, as was the case before the NDC gave rise to a succession of groundbreaking, multidisciplinary analyses, researching news media, crime and justice in the UK fell to those outside criminology. The studies that emerged in this post-Marxist climate, including those conducted by members of the three Centres, would foreground different elements of news selection and production, challenging the determinism that had characterised so much critical research and seeking a more holistic understanding of the mass communication process.

\section{Post-Marxist Interventions}

Throughout the 1980s the theoretical homogeneity that characterised the period of predominantly Marxist research on news media, crime and justice gave way to a more pluralistic period of theoretical development. A growing body of media research came to challenge what was perceived as the over-determinism inherent within Marxist variants of the control paradigm, most explicit in instrumental readings of news production, but also evident in structuralist work. The underpinning idea that, in the last instance, the news media operate as a 'largely uncritical conduit for official views' (Schlesinger, Murdock and Elliot, 1983: 166), was identified as a particular point of contention. The conception of dominant ideology was also diversified in this period to explore the ideological legitimation of inequalities not only in terms of class, but also in terms of gender, race and other social divisions. And new theoretical frameworks emerged that focused on aspects of the social formation other than class.

Over three books that remain widely cited in British research today, Ericson, Baranek and Chan $(1987 ; 1989 ; 1991)$ produced a highly sophisticated and detailed analysis of journalistic practices, source activities, and the role of news as an agency of social control across Canadian television, press and radio. Through a combination of content analysis, interviews and ethnographic observation they explore how journalists and sources engage in 'legitimation work' in the representation of crime and justice, and how news contributes to the formation of a stable 'symbolic canopy', based on but not restricted to dominant ideology, that helps to reinforce the 'consensual paradigm' for society as a whole (Ericson et al, 1987: 27-43). Ericson et al are avowedly anti-instrumentalist in their approach. And whilst they draw much from the structural Marxist work of Hall et al (1978) and Chibnall (1977), the political economy work of the CMCR, and the methods of the GUMG, they remain critical of the determinism inherent within the control paradigm. Research has consistently reaffirmed the asymmetrical relations between journalists and powerful sources, they argue, because it has been 'grounded in the perspective of journalists' (ibid: 125 ) and thus overlooks the important levels of 'convergence' between media and source organisations. Consideration of source perspectives reveals that the police, for example, are constrained by news discourses just as journalists are constrained by police discourses: 'police-reporter transactions entail controls from both sides, and interdependency' (Ericson et al, 1989: 125). In Canada, just as in Britain, 'the police are the primary definers of crime 
and its control to the public' (1989: 123). But while the police 'controlled the primary definitions of the subject of address (crime, criminality and its control by the police), they sensed a loss of control over the specific terms of the communication process' (Ericson et al, 1989: 123). The news media 'provide a somewhat open terrain for struggles for justice, even though particular issues and institutional sources predominate. The documented variation by medium and market shows pluralism in meanings and values' (Ericson et al, 1991: i).

This challenge to the control paradigm was also reflected in British news media research. In a number of large-scale studies on the press and television coverage of terrorism, industrial conflict and crime, Schlesinger, Tumber, Murdock, and Elliott, in various combinations, argued that privileging journalist perspectives overlooks the complexities of source-media management strategies, inter-source competition and journalist-source power relations. In relation to representations of terrorism, for example, Schlesinger, Murdock and Elliott (1983: 32) find that, though official perspectives predominate, media images 'were a good deal more diverse and complex than simpler assumptions about television's relation to the state and to dominant ideology predict'. In direct reference to the structural-culturalist work of Hall et al (1978), Schlesinger, Tumber and Murdock (1991: 399) argue that "Primary definition', which ought to be an empirically ascertainable outcome, is taken instead to be an a priori effect of the privileged access of the powerful'. Combining content analysis and interviews with journalists and sources, these authors confirm that definitional advantage is structurally determined to a degree, but it can seldom be guaranteed (see also Schlesinger and Tumber, 1994). Access to the media is not, as Hall et al (1978: 59) would have it, simply granted 'as of right'. It needs to be won through a variety of carefully managed media methods and practices that can be subject to frequent disruption. Off the record disclosures and internal leaks cannot be totally managed. By definition these interventions may stray from the official line and diminish considerably the extent to which powerful institutions can maintain a coherent organisational voice, still less ensure definitional control in the news media. Nor does the theory of primary definition account for the actions taken by non-official sources to enter into and sometimes successfully reframe the terms of a given debate. Furthermore, the notion of journalistic 'structured subordination' fails to account for occasions on which media actively challenge powerful institutions on issues of policy or practice, or investigative exposés force undesired or unintended official responses (Miller, 1998, 1993; Greer and McLaughlin, 2010). Schlesinger and colleagues $(1983,1989,1991,1994)$ insist that flows of information between journalists and sources are more complex than Marxist readings suggested, and that the reproduction of elite ideas in news content, though structurally advantaged, is by no means guaranteed. The dominance of any ideological position should be considered an 'achievement rather than a wholly structurally determined outcome' (Schlesinger, 1989: 79).

These arguments against the control paradigm could only be mounted from within that paradigmatic framework. The dominant ideology thesis had, in effect, established the 'inferential structure' or 'primary definition' within which further discussion or debate took 
place. The fundamental problematic remained the reproduction of dominant ideology as defined through class. With the development of critical feminist research on crime reporting the control paradigm underwent some conceptual reconfiguration. Here, dominant ideology is no less important, but it is framed primarily in terms of gender, and relates to the tendency of news reports to reinforce gender stereotypes that maintain unequal power relations, including economic inequality, in a patriarchal society. Though critical feminist research on crime news has been plentiful (Cameron and Fraser, 1987; Soothill and Walby, 1991; Meyers, 1997), only a few studies have engaged in depth with production processes (see, for example, Chancer, 2003; Kitzinger and Skidmore, 1995). One important example, influential in the British context, is Benedict's (1992) radical feminist analysis of the reporting of five high profile sex crime cases in the US. Benedict worked as a journalist and a rape counsellor before entering academia. This professional insight supplements content analysis, interviews with journalists and editors, and an academic feminist reading of power, gender, race and class to explore the structural and cultural arrangements that shape press reporting of sexual violence against women. The central theme is the prevailing tendency to polarise women in sex crime cases into either 'virgins' or 'whores' (ibid.: 26). It is suggested that the press' insensitive and sometimes cruel treatment of women in sex crime cases is seldom due to individual malice. Rather, it results from characteristics of society that are deeply embedded within the culture, namely the gender-biased nature of language and prevailing myths about women, sex and rape. These myths, or dominant ideological meanings, guide how news is both produced and processed, but do so implicitly in a way that can influence even the most well meaning commentators. Thus, 'a myth-saturated woman will be just as insensitive to rape cases as a myth-saturated man, especially given the conditions and habits of newsroom behaviour' (1992: 6). This is structural-culturalism read through gender. Of course, much critical feminist research retains a clear Marxist sensibility, and class, if not the defining factor, remains a core concern. In the period of postMarxist news media criminology, other frameworks emerged to further challenge class as the defining problematic.

For 'risk society' theorists, the transition from modernity to late-modernity has been characterised by a shift away from the focus on economic inequality and toward the nature, patterning and control of 'risk' (Beck, 1992). Whereas modernity was characterised by the positive problem of acquiring 'goods' (income, education, housing and health), the 'risk society' is characterised by the negative problem of avoiding 'bads' (global warming, AIDS, pollution... and crime). In the unequal society, the distribution of 'goods' could be broadly understood in terms of class. In the unsafe or 'risk' society, 'bads' are global and affect everyone more or less equally, regardless of class position. Collectivism is replaced by individualism. The state and its agencies are problems rather than solutions. Remedies to problems are not to be found in social policy, but in changing the behaviour of the people responsible (Reiner et al, 2001). In the shift from the class society to the risk society, the control paradigm's focus on dominant ideology loses purchase. It is the 'risk society' that provides the conceptual framework for Reiner, Allen and Livingstone's $(2000,2001)$ 
research on media representations of crime and justice in the post-War era. They find that over time news reports of criminal offending include less acknowledgement of possible structural causation and more condemnation of what is presented as individual evil. Portrayals of criminal justice remain broadly supportive, but are increasingly complex and critical, focusing more, for example, on police ineffectiveness, systemic corruption, and conflict between official institutions. And, in the most significant change, crime victims shift from being incidental characters to becoming the central focus for highly emotionalised news stories built around their experiences of suffering (Reiner et al., 2000: 187). The study does not engage with the news production process (though it does engage with audiences), and thus does not address changing journalist-source relations. But the risk society is a useful theoretical framework within which to explore media representations of crime and justice, and the changing political and cultural sensibilities that shape the late modern condition. Given the extent to which the thesis has been embraced by criminologists, it is surprising that it has not featured in more criminological analyses of the news.

\section{Theoretical Concepts}

Theoretical perspectives rise and fall, and drift in and out of academic favour. Theoretical concepts have an enduring and defining significance: they can be radically theorised and theorised in radically different ways, but they exist independently of the various theoretical positions within which they may be situated. As such, theoretical concepts are more than just research sites; they have an existence and life of their own. Three concepts that continue to shape the research agenda in news media criminology are newsworthiness, fear of crime and moral panics.

\section{Crime Newsworthiness}

Journalists' decisions regarding newsworthiness - which events to select for inclusion as news, and how to present those events once selected - are informed by their sense of 'news values'. The first academic exploration of news values was presented by Norwegian media researchers Galtung and Ruge (1965). Their analysis resulted in the identification of twelve news values that, they suggested, work collectively to inform the selection and production of events as news. This theoretical framework has been adopted and adapted by myriad researchers since, and features prominently in many of the studies discussed above. Remarkably, Galtung and Ruge's (1965) original insights were based on content analysis and, as they put it, 'a simplified psychology of perception and some additional assumptions' (1965: 64). No journalists or sources were interviewed or observed. 'The proper thing to do', they conceded, 'in order to test their validity would be to observe journalists at work... and we have no such data. For want of this the [news values] should be anchored in general reasoning and social science findings' (1965: 66). Forty years later, after much empirical testing, it is striking how well their framework still stands up to scrutiny . 
There are of course variations in emphasis and articulation across studies, and some more substantive differences, but the different accounts are most notable for their similarities. A consideration of news values helps us understand the nature of media content. Crime and justice events that are technologically accessible, easy to visualize, meet the required threshold for news visibility and fit within the routines and cycles of news production are more likely to be covered than abstract issues and debates that develop over longer periods. This event-orientation promotes a corresponding focus on individuals (as victims, offenders, justice officials). Individualization and personalization promote the simplification of news stories and serve to reinforce the common association between criminality and individual pathology rather than wider social, structural and political factors. Interpersonal crimes of sex and violence can be more easily presented as dramatic and titillating than non-violent crimes - for example, most property offences - particularly when they have high levels of proximity (spatial nearness and cultural meaningfulness) to the consumer. Crimes are more newsworthy if they are particularly audacious, violent or novel, involve famous or notable people, or take place in famous or notable places. Crimes are also more likely to be reported if they feature 'ideal victims', for example young children or older people, and there is a risk of further attacks.

Most sociological accounts have explored newsworthiness from the perspective of journalists, prioritizing their consideration of the pragmatics of news production, their assumptions about audience interests, and their assessment of the likely relevance and impact of the story on those audiences. The focus is on the background factors organizational, ideological, cultural, economic - that shape the selection and production of crime as news, prior to its dissemination to audiences. However, Katz (1987) points out that 'whatever the influences on new organizations that affect their selection and rejection of particular stories, daily newsreaders have an independent fascination with the stories that are published' (Katz, 1987: 48). Katz thus theorises newsworthiness from the perspective of the consumer, and is interested in understanding the symbolic relevance and psycho-social utility of crime news. The principal focus here, then, is on the foreground factors existential, moral, emotional - that make crime news 'required reading' for people on a daily basis. Whilst 'novelty' had been identified as a key determinant of crime newsworthiness across most research studies, Katz offers a different interpretation. His analyses suggests that the most newsworthy crimes seldom appear to be particularly unexpected or novel. Political scandals and stories of high level corruption confirm for many what they knew all along, yet such stories invariably attract considerable media attention. Banks are routine targets for robberies, yet they continue to generate substantial media interest when they are hit. If the key to understanding crime newsworthiness is not its unexpectedness, Katz argues (1987: 63), a more fruitful approach may be to consider crime's 'symbolic value in articulating the normatively expected'. From this perspective, crime is not newsworthy because it appeals to readers' base or morbid interests, or because it shocks them in the short term, or frightens them in the long term. Rather, crime is newsworthy because its reporting presents readers with the opportunity to engage in a 
daily ritual moral workout, allowing them to question and confirm (or otherwise) their own moral fortitude. In essence, crime news 'speaks dramatically to issues that are of direct relevance to readers' existential challenges, whether or not readers are preoccupied with the possible personal misfortune of becoming victims to crime' (Katz, 1987: 68).

\section{Fear of Crime}

There has been much debate around an adequate definition of fear that might be applied to explorations of news media - or other factors - and fear of crime (Hope and Sparks, 2000). Some commentators have queried the apparent academic preoccupation with endowing the concept of 'fear' with essentialist qualities that, for the purposes of longitudinal and comparative research, persist across time and place (Bourke, 2005). Others have questioned the tendency to characterise fear of crime as an unqualified social ill, and asked if some level of 'functional fear' - as opposed to 'dysfunctional worry' - might in fact be 'a motivating force that encourages vigilance and stimulates precautionary activity' (Jackson and Gray, 2010). Particularly within the context of high crime societies, purportedly characterised by 'existential anxiety' and 'ontological insecurity' and giving rise to 'criminologies of everyday life' (Giddens, 1991; Bauman, 1997; Garland, 2001), 'fear' can become a catchall phrase used to describe any range of emotional responses. It can be intimately connected, for example, with anger, distrust, shame, jealousy and rage, as well as vigilance, consideration and caution, and cannot be easily isolated for empirical analysis. What is most important, argues Bourke (2005), is the social and cultural context in which the term is used, when it is used, and by whom.

The most widely cited body of literature on media and fear of crime also clearly demonstrates some of the main conceptual and methodological problems within this field of research. Gerbner et al's 'cultivation research' has over several decades explored the correlation between viewing television violence and beliefs regarding politics, public safety and social order (Gerbner and Gross, 1976; Gerbner et al., 1994). The central finding is that 'heavy' television viewers cultivate a world-view which more closely resembles the 'television message' than 'light' television viewers. Because television overstates both the seriousness and risk of criminal victimization, portraying the world as 'mean and scary', heavy viewing is said to cultivate higher fear of crime. Fearful citizens tend to be depoliticised, more dependent on established authority, more punitive, and more likely to acquiesce to authoritarian measures of control. The now well rehearsed problems with the cultivation project include: its simplification and de-contextualising of the categories 'media', 'violence' and 'fear'; its attempts to quantify the creative and highly variable processes of interpretation and influence; and its search for a straightforward causal connection between media and fear of crime (Sparks, 1992; Ditton et al, 2004). Yet the central claim underpinning cultivation research - that particular forms of distorted and distorting media communication can generate widespread anxiety, punitive sentiments, and the tacit acceptance of authoritarian governance - finds much wider support. This position is explicit in Hall et al's (1978) Policing the Crisis, where it is read through a Gramscian 
reading of the state's repressive response to a 'crisis in hegemony'. It is central to recent and widespread claims that the state is harnessing a culture of fear in a post-9/11 risk society in order to legitimate tough anti-terror legislation or, more generally, to govern through crime (Simon, 2006; Mythen and Walklate, 2006; Furedi, 2005). Analysts of 'penal populism', now an organising concept within criminology, have been at pains to understand the roles of mass media and fear of crime, both individually and in terms of their interconnections, in the apparent rise of punitive sentiment and the collapse of faith in the ability of authorities to deliver public protection (Bottoms, 1995; Roberts et al, 2003; Pratt, 2007). Yet empirically substantiating the intuitive connection between these variables remains elusive.

The more revealing research has moved beyond the search for simplistic causal connections, and sought to develop a contextually aware understanding of media and fear of crime. Kitzinger and Skidmore's (1995: 12) study on news coverage of child sex abuse uses mixed-methods to explore news content, production and, crucially, consumption and influence. Both members of the Glasgow University Media Group, Kitzinger and Skidmore were instrumental in developing the GUMG's particular brand of audience research. Here, focus groups are run to assess 'the potential and limits of people's ability to deconstruct and 'resist' media accounts' (1995: 1). The group discussions raised the useful distinction between intellectual and emotional knowledge. While most participants 'knew' abuse happened more often in domestic or institutional settings, 'their fear often focused on external sites such as woodland or wasteland' (ibid.: 9). And though many 'knew' that abuse is most often committed by someone the child knows, 'their fear focused on strangers' (ibid.: 9). In fact, they argue, 'audience understandings of how they might detect child abuse, the sources of danger and their ideas about intervention were often in conflict with the information which children's charities and social work agencies are trying to promote' (ibid.: 8). This contextual understanding of media and fear of crime has been probed further by Ditton et al (2004), whose combination of quantitative questionnaires and qualitative interviews revealed that it is not the 'objectively determined randomness, localness or sensationalism that is important, but rather the interpretation of media content as relevant to and by the consumer' (Ditton et al., 2004: 607).

\section{Moral Panics}

The term 'moral panic' was first used by Young (1971) in his study of subcultures and drugtaking. Cohen (1972) developed and extended the concept in his analysis of the sensationalistic, heavy handed and ultimately 'disproportionate' reaction to the Mods and Rockers disturbances in an English seaside resort in 1964. Though the damage was in financial terms minor, Cohen traces the spiralling social reaction through initial intolerance, media stereotyping, moral outrage, increased surveillance, labelling and marginalisation, and deviancy amplification leading to further disturbances that seemed justify the initial concerns. The flamboyant misbehaviour of youth subcultures, independent and sexually and economically liberated, affronted the post-War values of hard work, sobriety and deferred 
gratification. At a time of rapid social change, they were a visible index of a world that was slipping away - 'folk devils' who provided a crystallising focus for social anxiety and 'respectable fears'. Reflecting the pluralistic theoretical interests of the NDC, Cohen built upon social constructionism, symbolic interactionism, deviancy amplification and labelling, but also incorporated the lesser known academic literature on 'disaster research' to describe the various phases of a moral panic - warning, impact, inventory, reaction - and chart its progression. In his analysis of the mass communication process, he drew in particular from the Leicester CMCR's work on 'inferential structures' (Halloran et al, 1970). These theoretical resources were combined with in depth content analysis, questionnaires, interviews, and voluntary work in the local community to develop a fully sociological account of youth, culture, change and anxiety in post-War Britain.

Hall et al (1978) politicised the concept of moral panic. In their analysis of a 'mugging' moral panic as an ideological intervention to address an escalating crisis in state hegemony (see above), it was inevitable that the concept would be read through the CCCS's particular form of structural Marxism. Yet Policing the Crisis draws also from an eclectic mix of influences, connecting 'new deviancy theory, news media studies and research on urban race relations with political economy, state theory and notions of ideological consent' (McLaughlin, 2008: 146). For some critical criminologists, it represents the high point of Marxist theorising about crime, law and order and the state (Crime, Media, Culture, Special Section, 4,1). Acknowledging the sophistication within the CCCS work, Cohen (2007) has nonetheless noted a wider tendency to over-politicise the concept at the expense of its sociological meaning and application. Hall (2007) has suggested in response that politicisation was a necessary developmental stage, and that the full explanatory potential of the moral panic concept was, in fact, only realised through its construction as ideology.

Goode and Ben Yehuda (1994) developed Cohen's discussion of moral panic by paying particular attention to the criteria that should be in place before it can be suggested that a 'moral panic' is occurring. They identify five key features of the phenomenon: (i) concern (a reported condition or event generates anxiety); (ii) hostility (the condition or event is condemned and, where there are clearly identifiable individuals who can be blamed, these are portrayed as 'folk devils'); (iii) consensus (the negative social reaction is widespread and collective); (iv) disproportionality (the extent of the problem and the threat is poses are exaggerated); (v) volatility (media attention and the associated panic emerge suddenly and with intensity, but can dissipate quickly too).

'Moral panic' is one of the most widely used terms in the sociological analysis of crime and justice, and has transcended academic discourses to become commonplace in political rhetoric and popular conversation (Altheide, 2009). Given its prolific usage, it is surprising that few commentators have subjected the concept to sustained and rigorous critical investigation. With the split in the criminological left in the late-1970s, the concept was dismissed by Left Realists as 'left idealism', and accused of obfuscating the painful 'realities' of criminal victimisation by propagating the view that 'the crime problem' is socially constructed (Young, 1979). In exploring the anatomy of the concept, critics have 
queried the notions of 'disproportionality' and 'volatility'. The first, since this assumes a superior knowledge of the objective reality of the issue against which the reaction is measured, and a corresponding assumption of what a 'proportionate' reaction would look like (Waddington, 1986). The second, because in a contemporary multi-media world characterised by ontological insecurity and state of a permanent free-floating anxieties, the notion of discreet, self-contained, volatile moral panics may need some rethinking (McRobbie and Thornton, 1995). Cohen has responded to all of these criticisms (Cohen, 2002). But such critical interventions, both from within and outside of criminology, have barely interrupted the general tendency to arbitrarily apply the concept to explain everything from global warning to 'Swine Flu'. The broadly uncritical application of the moral panic concept has led Garland (2008) to reassert two elements of the original analysis, which are absent from many contemporary studies: (i) the moral dimension of the social reaction - most issues can be moralised, but many are not in and of themselves 'moral', and cannot automatically be analysed as such; and (ii) the idea that the deviant conduct in question is somehow symptomatic of a wider problem - a threat to established values, or a particular way of life.

\section{Theoretical Dilemmas}

In order to make sense of contemporary news media representations of crime and justice, it is necessary take account of dramatic changes in both the crime and justice and media arenas, and to engage in depth with the increasingly interactive relationship between them. Within criminology there is now a substantial literature detailing transformations across the crime and justice landscape. Different scholars foreground different elements and explain them in different ways, but the commonalities across accounts are significant, and include: the ascendancy of neo-conservative, populist criminologies, the politicisation of law and order and the rise of 'governing through crime', the emergence of victim-centred justice, the re-emotionalisation of crime and justice, net-widening and 'defining down' of deviance and, underpinning all of this, the hypermediatisation of crime, control and social order (Garland, 2001; Ericson, 2006; Simon, 2006; Reiner, 2007; Young, 2007).

This process of hypermediatisation has taken place across a rapidly changing media environment. There are more news platforms, sites and formats than ever before, and the sheer amount of available information is unprecedented. Within an intensely competitive market, news becomes increasingly commodified and journalists increasingly adversarial, while sources of all kinds become more professional and adept at dealing with the media. Faced with greater choice in a diversified and highly interactive environment, media-savvy news audiences fragment. This 24-7 global news mediasphere is light-years from the altogether more homogenous conditions explored in Marxist and Post-Marxist analyses of reporting crime. As the media environment has changed, so has the terrain upon which struggles over media power and influence are played out. As McNair puts it (2006: 49): 
News... is not manufactured (neither, therefore, is consent), nor is it 'constructed'. Nor does it just happen. It emerges from the interacting elements of the communication environment which prevails in a given media space. These spaces contain many social actors striving to manufacture and shape the news, but none has any guarantee of success... [J] ust as no amount of meteorological data-gathering can make the weather entirely predictable, so no social actor, be he president, prime minister or pope, can predict with any certainty what tomorrow's news will contain.

In the UK, an already fragmented government struggles to control the crime news agenda in a climate where the putative 'facts' of the crime problem - as derived from official statistics, victim surveys, performance indicators - are spun into a web of conflicting narratives, used simultaneously by competing interests as evidence of success and failure, or dismissed altogether as fabrication and 'moral panic'. Hyper-adversarial press reporters go on the attack (Barnett, 2002; Fallows, 1996), subjecting official institutions and their senior managers - the police, the courts, the prison service, government offices - to a constant barrage of criticism for failing to deliver in the democratically mandated task of 'public protection'. Media campaigns are launched in the name of high profile crime victims, whose increasingly vociferous and empowered representatives now routinely employ professional PR advisers to make their cases more 'media-friendly', and therefore more suitable to widespread public articulation and dissemination. Media audiences, tired of the 'permanent crisis in criminal justice', are actively encouraged to participate in the news production process. The rise of the 'citizen journalist', capable not only of emailing, texting or phoning in their views and concerns, but also of providing news organisations with live footage of events as they happen, presents an additional challenge to official institutional attempts to manage the news process (Gilmour, 2004). Where citizens were once content to consume the news, today they are increasingly involved in producing it. producing it. The classic modernist frameworks for understanding crime and justice news still have much to offer. But they cannot embrace the complexity of contemporary flows of communication power and associated perceptions of public credibility in the 24-7 global news mediasphere.

Though transformations in the crime and justice and media landscapes have been well documented separately, their complex interaction has yet to be adequately explored. As this chapter has illustrated, many if not most of the defining studies on news media, crime and justice have come from outside criminology. The foundational Marxist studies from the Centres at Birmingham, Leicester and Glasgow, the interdisciplinary works emerging from the NDC, and the diverse Post-Marxist interventions were mostly situated within sociology, media studies and cultural studies. Likewise many of the most significant developments or critical commentaries on core theoretical concepts - newsworthiness, fear of crime, moral panics. Yet whilst the sociology of media and communications and cultural studies have moved on, news media criminology all too frequently remains locked-in to a now outdated framework of understanding. 
The interdisciplinary, engaged and sustained news media research that defined the Marxist and early Post-Marxist periods, has been replaced with a growing reliance on superficial content analysis. This is no doubt partly attributable to logistical convenience. The emergence of online searchable newspaper databases allow researchers to search, retrieve, collate and examine entire bodies of news coverage at the push of a button. The analysis of text-based documents can of course reveal much in terms of the meanings given to crime and criminal justice in news discourses. But online newspaper databases strip news content of its form, colour and style - erasing visual imagery and surrounding stories and context. News media analyses are thus increasingly based upon a 'news residue' standardised, decontextualised words on a computer screen (Greer, 2009). The visual is perhaps 'the' defining characteristic of news media today. Since visual attractiveness has always been fundamental to television, studies on news broadcasting have naturally featured some discussion of visual as a defining characteristic (Golding and Elliott, 1979; Schlesinger et al, 1983; Chermak, 1995; Cottle, 2006). Yet whilst the image has always been fundamental to printed news, there has until recently been little engagement with the visual in criminological studies of the press (Hayward and Presdee, 2010; Jones and Wardle, 2008; Greer, 2003). In a increasingly visual context of hypermediatisation, attention to news images must surely be a priority. Furthermore, the rise in news media content analysis has been paralleled with a corresponding decline in research on the news production process. Criminologists are no longer engaging with journalists or sources. Finally, with the exception of research on fear of crime, news media criminology has tended more often to assume than evidence media influence. This was a fundamental dilemma that the GUMG sought to address in their research, but news media criminology has been slow to capitalise on the availability of methodological approaches which can start to make meaningful sense of the influence on consumers of media images of crime and justice. Even Cultural Criminology, which is highly sensitised to issues of media and mediatisation, has thus far had little to say on the news media (Greer, 2009).

Criminology does not currently have the intellectual resources to apprehend the massive transformations across the news media environment in recent decades, the visually spectacular presentation of crime news as a hypercommodified product, or the increasingly interactive manner in which it is created and consumed. What is needed is the systematic testing of new theoretical ideas and empirical questions: how chaotic is the global news mediasphere; how much influence can powerful source organisations retain in this climate; is it possible to manage, if not control, the news process? who are the primary definers in the global news mediasphere? Answering these questions requires the development of new theoretical and methodological tools that permit the sustained and in depth engagement with the contemporary media environment. The acquisition and application of such tools in turn requires a renewed focus on interdisciplinarity. 


\section{References}

Altheide, D. (2009) 'Moral Panic: From Sociological Concept to Public Discourse', in Crime, Media, Culture: An International Journal, 5, 1: 79-99.

Althusser, L. (1971) 'Ideology and the State', in Lenin and Philosophy and Other Essays, London: New Left Books.Bauman, Z. (1997) Postmodernity and its Discontents, Cambridge: Polity.

Barnett, S. (2002) 'Will a crisis in journalism provoke a crisis in democracy', Political Quarterly, 73:4, pp.400-408.

Beck, U. (1992) The Risk Society: Towards a New Modernity, London: Sage.

Becker, H. (1967) 'Whose Side Are We On', in The Relevance of Sociology, Douglas, J. D., (ed.), (1970) New York, Appleton-Century Crofts.

Becker, H, (1963) Outsiders - Studies in the Sociology of Deviance, New York: Free Press of Glencoe.

Benedict, H. (1992) Virgin or Vamp: How the Press Covers Sex Crimes, Oxford: Oxford University Press.

Bennett, T. (1982) 'Media, Reality, Signification', in M. Gurevitch, T. Bennett, J. Curran \& J. Woollacott (Eds.) (1982) Culture, Society and the Media. London: Methuen.

Blackman, S. (1998) 'The School: 'Poxy Cupid'. An Ethnographic and Feminist Account of a Resistant female Youth Culture: The New Wave Girls' in Skelton, T. and Valentine, G. (eds.) Cool Places: Geographies of Youth Cultures, London: Routledge.

Boorstin, D. (1963) The Image, Harmondsworth: Penguin Books.

Bottoms, A.E. (1995) 'The Philosophy and Politics of Punishment and Sentencing', in C. Clarkson and R. Morgan (eds.) The Politics of Sentencing Reform. Oxford: Clarendon.

Bourke, J. (2005) Fear: A Cultural History, London: Virago.

Brundson, C. and Morley, D. (1978) Everyday TV: Nationwide, London: British Film Institute.

Cameron, D. and Frazer, E. (1987) The Lust to Kill: A Feminist Investigation of Sexual Murder, Cambridge, Polity Press.

Chancer, L. (2003) High Profile Crimes: When Legal Cases Become Social Causes, Chicago: University of Chicago Press.

Chermak, S. (1995) Victims in the News: Crime and the American News Media. Boulder, CO: Westview Press.

Chibnall, S. (1977) Law and Order News: An Analysis of Crime Reporting in the British Press. London: Tavistock.

Curran, J., Gurevitch, M. and Woollacott, J. (1982) 'The Study of the Media: Theoretical Approaches', in M. Gurevitch, T. Bennett, J. Curran \& J. Woollacott (Eds.) (1982) Culture, Society and the Media. London: Methuen.

Cohen, S. (2007) Moral Panics Then and Now, panel discussion at the British Academy, $9^{\text {th }}$ March, 2007 (available at http://www.britac.ac.uk/perspectives/0703moralpanics.cfm).

Cohen, S. (1972/2002) Folk Devils and Moral Panics: The Creation of the Mods and Rockers. London: MacGibbon and Kee (third edition, Routledge, 2002). 
Cohen, S. and Young, J. (eds) (1973) The Manufacture of News: Social Problems, Deviance and Mass Media, London: Constable (revised edition 1981).

Cottle, S. (2006) Mediatized Conflict: Developments in Media and Conflict Studies Buckingham: Open University Press.

Cumberbatch, G. (1989) 'Violence in the Media: The Research Evidence', in G. Cumberbatch and D. Howitt (eds) A Measure of Uncertainty: the Effects of the Mass Media. London: John Libbey.

Davies, P., Francis, P. and Greer, C. (eds) (2007) Victims, Crime and Society. London: Sage.

Ditton, J., Chadee, D., Farrall, S., Gilchrist, E. and Bannister, J. (2004), 'From Imitation to Intimidation: A Note on the Curious and Changing Relationship Between the Media, Crime and Fear of Crime', British Journal of Criminology, 44, 4: 595-610.

Eldridge, J. (2006) 'The Work of the Glasgow Media Group: An Insider's Story', in D. Berry and J. Theobold (eds.) Radical Mass Media Critcism: A Cultural Geneology, London: Black Rose Books.

Ericson, E. (2006) Crime in an Insecure World, Cambridge, Polity Press.

Ericson, R., Baranek, P. and Chan, J. (1987) Visualising Deviance: A Study of News Organisation. Milton Keynes: Open University Press.

Ericson, R., Baranek, P. and Chan, J. (1989) Negotiating Control: A Study of News Sources. Milton Keynes: Open University Press.

Ericson, R., Baranek, P. and Chan, J. (1991) Representing Order: Crime, Law and Justice in the News Media. Milton Keynes: Open University Press.

Fallows, J. (1996) Breaking the News: How the Media Undermine American Democracy, New York: Pantheon Books.

Furedi, F. (2005) Politics of Fear, London: Continuum.

Furedi, F. (2002) Culture of Fear, London: Continuum.

Galtung, J. and Ruge, M. (1965) 'The Structure of Foreign News: The Presentation of the Congo, Cuba and Cyprus Crises in Four Norwegian Newspapers', Journal of Peace Research, 2, 1: 64-91.

Garland, D. (2008) 'On the Concept of Moral Panic', in Crime, Media, Culture: An International Journal, 4, 1: 9-30.

Garland, D. (2001) The Culture of Control: Crime and Social Order in Contemporary Society, Oxford: Oxford University Press.

Gerbner, G. and Gross, L. (1976) 'Living with Television: the Violence Profile', in Journal of Communication, 26, 1: 173-99.

Gerbner, G., Gross, L., Morgan, M. and Signorielli, N. (1994) 'Growing up with Television; The Cultivation Perspective', in J. Bryant and D. Zillman. (eds) Media Effects. Hillsdale, NJ: Lawrence Erlbaum.

Giddens, A. (1991) Modernity and Self-Identity, Cambridge: Polity.

Gillmor, D. ( 2004) We the Media: Grassroots Journalism by the People, for the People, Sebastopol, CA: O'Reilly Media.

Glasgow University Media Group (1976) Bad News, London: Routledge. 
Glasgow University Media Group (1980) More Bad News, London: Routledge.

Golding, P. and Murdock, G. (2000) 'Culture, Communications, and Political Economy,' in J. Curran and M. Gurevitch (eds.) Mass Media and Society, third edition, London: Edward Arnold.

Golding, P. and Elliott, P. (1979) Making the News, London, Longman.

Golding, P. and Murdock, G. (1979) 'Ideology and Media: the Question of Determination, in Barrett, M., A. Kuhn, Wolff, J. and Corrigan, P. (ed.) Ideology and Cultural Production, London: St Martin's Press.

Goode, E. and Ben-Yehuda, N. (1994) Moral Panics: The Social Construction of Deviance, Oxford: Blackwell.Green, D. (2008) When Children Kill Children: Penal Populism and Political Culture, Oxford: Oxford University Press.

Greer, C. (ed.) (2009) Crime and Media: A Reader, London: Routledge,

Greer, C. (2003) Sex Crime and the Media: Sex Offending and the Press in a Divided Society, Cullompton: Willan

Gunter, B. (1987) Television and the Fear of Crime. London: John Libbey.

Hale, C. (1996) 'Fear of Crime: A Review of the Literature', in International Review of Victimology, 4: 79-150.

Hall, S. (2007) Moral Panics Then and Now, panel discussion at the British Academy, $9^{\text {th }}$ March, 2007 (available at http://www.britac.ac.uk/perspectives/0703moralpanics.cfm).

Hall, S. (1982) 'The Rediscovery of Ideology', in M. Gurevitch, T. Bennett, J. Curran \& J. Woollacott (Eds.) (1982) Culture, Society and the Media. London: Methuen.

Hall, S. (1980) 'Introduction to Media Studies at the Centre', in S. Hall, D. Hobson, A. Lowe and P. Willis (eds.) Culture, Language, Media, London: Routledge.

Hall, S. (1977-78) 'Debate', Screen, London, winter 113.

Hall, S. (1973) 'The Determination of News Photographs', in Cohen, S. and Young, J. (eds.) The Manufacture of News: Social Problems, Deviance and the Mass Media, London: Constable.

Hall, S. (1971) 'A World at One with Itself', reproduced in Cohen, S. and Young, J. (eds.) (1973) The Manufacture of News: Social Problems, Deviance and the Mass Media, London: Constable.

Hall, S. Critcher, C. Jefferson, T. Clarke, J. and Roberts, B. (1978) Policing the Crisis: Mugging, the State and Law and Order. London: Macmillan.

Hall, S. and Jefferson, T. (1976) Resistance Through Rituals: Youth Subcultures in Post-War Britain, London: Routledge.

Halloran, J., Elliott, P. and Murdock, G (1970) Demonstrations and Communication. A Case Study. Harmondsworth: Penguin.

Hamm, M. (2007) 'High Crimes and Misdemeanors: George Bush and the Sins of Abu Ghraib', in Crime, Media, Culture: An International Journal, 3, 3,: 259-284.

Hayward, K. and Presdee, M. (eds.) (2010) Framing Crime: Cultural Criminology and the Image, London: Routledge.

Hebdige, D. (1979) Subculture: The Meaning of Style, London: Routledge. 
Herman, E. and Chomsky, N. (1988) Manufacturing Consent: The Political Economy of the Mass Media, New York: Pantheon.

Hope, T. and Sparks, R. (eds.) (2000) Crime, Risk and Insecurity: Law and Order in Everyday Life and Political Discourse, London: Routledge.

Hough, M., Indermaur, D., Roberts, J. and Stalans, L. (2003) Penal Populism and Public Opinion: Lessons from Five Countries, New York: Oxford University Press.

Jackson, J. and Gray, E. (2010) 'Functional Fear and Public Insecurities About Crime', in British Journal of Criminology, 50, 1: 1-22.

Jefferson, T. (2008) 'Policing the Crisis Revisited: The State, Masculinity, Fear of Crime and Racism', in Crime, Media, Culture: An International Journal, 4, 1: 113-121.

Jewkes, Y. (2004) Media and Crime. London: Sage.

Jones, P. and Wardle, C. (2008) 'No Emotion, No Sympathy': The Visual Construction of Maxine Carr, Crime Media Culture: An International Journal; 4, 1: 53-71.

Katz, J. (1987) 'What Makes Crime News', in Media, Culture and Society, 9, 1: 47-76. Kitzinger, J. and Skidmore, P. (1995) 'Child Sexual Abuse and the Media', Summary Report to ESRC. Award no. R000233675. Report available from Glasgow Media Group.

Lang, K. and Lang, G. (1955) 'The Inferential Structure of Political Communications: A Study in Unwitting Bias', Public Opinion Quarterly, 19: 168-183.

McLaughlin, E. (2008) 'Hitting the panic button: policing/'mugging'/media/crisis', in Crime, Media, Culture: An International Journal, 4, 1: 145-154.

McNair, B. (2006a) Cultural Chaos: Journalism, News and Power in a Globalised World, London: Routledge.

McNair, B. (2006b) 'The Culture of Chaos', in The Guardian, May $1^{\text {st }} 2006: 1$.

McRobbie, A. and Thornton, S. (1995) 'Rethinking "Moral Panic" for Multi-Mediated Social Worlds', in British Journal of Sociology. 46, 4: 559-74.

Meyers, M. (1997) News Coverage of Violence Against Women: Engendering Blame, Thousand Oaks, London: Sage.

Miller, D. (1998) 'Public Relations and Journalism: Promotional Strategies and Media Power', in A. Briggs and P. Cobley (eds.) The Media: An Introduction, London: Longman.

Miller, D. (1993) 'Official Sources and "Primary Definition": The Case of Northern Ireland', Media, Culture and Society, 1993, vol. 15, 385-406.

Morley, D. (1980): The 'Nationwide' Audience: Structure and Decoding. London: British Film Institute.

Murdock, G. (1982) 'Large Corporations and the Control of the Communications Industries', in M. Gurevitch, T. Bennett, J. Curran \& J. Woollacott (Eds.) (1982) Culture, Society and the Media. London: Methuen.

Murdock, G. (1973) Political Deviance: The Press Presentation of Militant Mass Demonstration', in Cohen, S. and Young, J. (eds.) The Manufacture of News: Social Problems, Deviance and the Mass Media, London: Constable. 
Murdock, G. and Golding. P. (1977) 'Capitalism, Communication and Class Relations', Curran, J. and Gurevitch, M. (ed.) Mass Communication and Society, London: Arnold. Murdock, G. and Golding. P. (1974) 'Communication: the Continuing Crisis', New Society, $25^{\text {th }}$ April 1974: 179-181.

Mythen, G. and Walklate, S. (2006) 'Communicating the Terrorist Risk: Harnessing a Culture of Fear', in Crime, Media, Culture: An International Journal, 2, 2: 123-142.

Philo, G. (1999) 'Good News: the Glasgow University Media Group', Variant, 2, 7: 2-4.

Philo, G, and Miller, D. (2001) 'Media/Cultural Studies and Social Sciences', in G. Philo and D. Miller (eds.) Market Killing: What the Free Market Does and What Social Scientists can do About it, London: Longman.

Pratt, J. (2007) Penal Populism, London: Routledge.

Reiner, R. (2007) Law and Order: An Honest Citizen's Guide to Crime and Control, Cambridge: Polity.

Reiner, R., Livingstone, S. and Allen, J. (2000a) 'Casino culture: media and crime in a winnerloser society' in K. Stenson and D. Cowell (eds) Crime, Risk and Justice. Cullumpton: Willan.

Reiner, R., Livingstone, S. and Allen, J. (2000b) 'No more happy endings? The media and popular concern about crime since the Second World War', in T. Hope and R. Sparks (eds) Crime, Risk and Insecurity. London: Routledge.

Sacco. V. (1982) 'The Effects of Mass Media on Perceptions of Crime: A Reanalysis of the Issues', in Pacific Sociological Review, 25, 4: 475-493.

Schlesinger, P. (1989) 'Rethinking the Sociology of Journalism: Source Strategies and the Limits of Media-Centrism', in , M. Ferguson (ed.) Public Communication: The New Imperatives, London: Sage.

Schlesinger, P. and Tumber, H. (1994) Reporting Crime: The Media Politics of Criminal Justice. Oxford: Clarendon Press.

Schlesinger, P., Tumber, H. and Murdock, G. (1991) 'The Media Politics of Crime and Criminal Justice', in British Journal of Sociology, 42, 3: 397-420.

Schlesinger, P. Murdock, G. and Elliott, P (1983) Televising "Terrorism" : Political Violence in Popular Culture, London: Commedia.

Simon, J. (2006) Governing Through Crime: How the War on Crime Transformed American Democracy and Created a Culture of Fear Oxford: Oxford University Press.

Soothill, K. and Walby, S. (1991) Sex Crime in the News, London: Routledge.

Sparks, R. (1992) Television and the Drama of Crime: Moral Tales and the Place of Crime in Public Life, Buckingham: Open University Press.

Waddington, P. (1986) 'Mugging as a Moral Panic: A Question of Proportion', in British Journal of Sociology, 37, 2: 245-59.

Wilkins, L. (1964) 'Information and the Definition of Deviance', reproduced in S. Cohen and J. Young. (eds.) (1973), The Manufacture of News: Social Problems, Deviance and Mass Media. Constable, London. 
Willis, Paul. Learning to Labour: How working-class Kids get working-class Jobs.

Farnborough: Saxon House.

Young, J. (2007) Vertigo of Late Modernity London: Sage.

Young, J. (2002) 'Critical Criminology in the Twenty-first Century: Critique, Irony and the Always Unfinished', in K. Harrington and R. Hogg (eds.) Critical Criminology: Issues, Debates, Challenges, Cullompton: Willan.

Young, J. (1979) "Left Idealism, Reformism and Beyond: from the New Criminology to Marxism' Fine. B., Kinsey, R., Lea, J., Picciotto, S. and Young, J. (eds) (1979) Capitalism and the Rule of Law: from Deviancy to Marxism, London: Hutchinson.

Young, J. (1971) 'The Role of the Police in the as Amplifiers of Deviancy, Negotiators of Reality, and Translators of Fantasy: Some Consequences of our Present System of Drug Control as Seen in Notting Hill', in S. Cohen and J. Young (eds.), Images of Deviance, Harmondsworth: Penguin. 